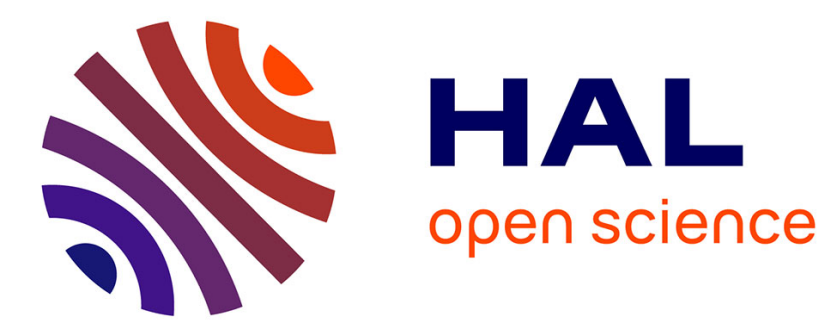

\title{
Crop management, labour organization, and marketing: three key issues for improving sustainability in organic vegetable farming
}

\author{
Mireille Navarrete, Lucie Dupre, Claire Lamine
}

\section{To cite this version:}

Mireille Navarrete, Lucie Dupre, Claire Lamine. Crop management, labour organization, and marketing: three key issues for improving sustainability in organic vegetable farming. International Journal of Agricultural Sustainability, 2014, 13 (3), pp.257-274. 10.1080/14735903.2014.959341 . hal-01198254

\author{
HAL Id: hal-01198254 \\ https://hal.science/hal-01198254
}

Submitted on 27 May 2020

HAL is a multi-disciplinary open access archive for the deposit and dissemination of scientific research documents, whether they are published or not. The documents may come from teaching and research institutions in France or abroad, or from public or private research centers.
L'archive ouverte pluridisciplinaire HAL, est destinée au dépôt et à la diffusion de documents scientifiques de niveau recherche, publiés ou non, émanant des établissements d'enseignement et de recherche français ou étrangers, des laboratoires publics ou privés. 


\title{
Crop management, labour organization, and marketing: three key issues for improving sustainability in organic vegetable farming
}

\author{
Mireille Navarrete $^{\mathrm{a} *}$, Lucie Dupré ${ }^{\mathrm{b}}$ and Claire Lamine ${ }^{\mathrm{a}}$ \\ ${ }^{a}$ INRA, UR767 Ecodéveloppement, F-84000 Avignon, France; ${ }^{b}$ INRA SADAPT Unit, 65, avenue de \\ Brandebourg, 94205 Ivry sur Seine cedex, France
}

\begin{abstract}
Most market-garden farms that have converted to organic farming (OF) in the last few decades in France are small and diversified. Larger farms usually specialize in a few vegetable species and frequently face technical and economic problems when they convert to organics. Diversifying production may be a means of increasing sustainability due to larger crop rotations and varied marketing outlets, but it has various implications on farm management, especially labour organization and marketing. In the present study, we examined how an acceptable degree of species diversification can act as a lever to develop organic vegetable production by combining sociologist and agronomist points of view. Multidisciplinary surveys of 30 market-garden farms varying in usable surface area and degrees of crop diversification were carried out. Consequences on crop management, labour organization and skills, and marketing implications were described, and farm sustainability was assessed. Specialized farms of the sample had a rather industrial organization of labour and marketing and benefited from economy of scale to produce vegetables. But in the long term, they may suffer from low agronomical sustainability because of narrow crop rotations and intensive crop management. Diversified farms were more sustainable according the criteria studied, but they suffered from the extremely complex management of cropping systems. These results are discussed on both the farm and territorial levels. Collective marketing initiatives and social networks might help reach an acceptable degree of species diversification at the farm level. Potential innovative organizations are identified, which could facilitate the transition to $\mathrm{OF}$.
\end{abstract}

Keywords: diversification; market-garden; labour; cropping system; market; farm; organic farming

\section{Introduction}

Various types of ecologically based agricultures have emerged in Europe in response to societal demands for more sustainable farming and healthier food: agroecology, integrated crop management, low input, biodynamic, organic agriculture, etc. (Rigby and Caceres 2001, Ollivier and Bellon 2013). They all encourage the development of biodiversity, which is liable to act as a buffer against environmental and economic fluctuations, reduce biological risks (Lin 2011), control pest outbreaks (Letourneau et al. 2011), and even strengthen resilience to climate change (Mijatovi et al. 2013). The term 'biodiversity' in the agricultural sector encompasses both natural and cultivated diversities and refers to temporal and spatial dimensions, at various scales: within the field, at the field, or at the landscape level (Lin 2011). Kremen et al. (2012) defined diversified farming systems as 'farming practices and landscapes that intentionally include functional biodiversity at multiple spatial and/or temporal scales in order to maintain

\footnotetext{
*Corresponding author. Email: mireille.navarrete@avignon.inra.fr
} 
ecosystem services that provide critical inputs to agriculture'. The main ecosystem services concerned are the control of weeds, diseases and pests, nutrient management but also pollination services (Kremen and Miles 2012). In particular, increasing crop diversity (i.e. the number of species cropped on a farm or plot) has gained a lot of attention from both scientists (Altieri 1999) and politicians (e.g. European regulation RCE no. 834/2007 on organic farming (OF)), because it links the environmental and production issues and may generate more sustainable systems (Kremen and Miles 2012). And yet, despite the scientific interest, crop diversity is not a common practice in most types of ecologically based agricultures in western countries. The phenomenon must be put in a context of specialization of agriculture, even in the organic sector which is part of what Buck et al. (1997) called the 'conventionalization process'. We hypothesize that one reason for the under-utilization of crop diversity is that the agronomic and environmental issues are closely intertwined with economic and social issues, such as work and labour organization, or selling outlets. Organic market-gardening is emblematic of the interactions between social and agronomic dimensions. First, given that it relies on huge manual workload and that OF partly depends on the substitution of synthetic inputs by labour, crop diversification questions labour organization on farm. Second, most vegetables are sold as fresh products; the diversity of products and their availability over time for markets directly depends on the degree of diversification and cropping patterns at the farm level.

Scientific literature dealing with the multi-dimensional issues of OF, taking into account both production and social practices, is sparse (Lamine and Bellon 2008). A few sociological studies have pointed out that the diversification of farms dramatically complicates crop management compared to mono-cropping situations: diversified farming systems require intensive skills and knowledge to crop a large number of species and even increase workload (Buck et al. 1997, Escalante and Santos 2010). In some cases, labour could even be one of the reasons for the abandonment of OF by some farms (Rigby and Young 2000). An interesting sociological question refers to how diversified farming systems deal with the question of labour on farm, and specifically as regards skills and labour organization (Dupré 2011).

The other key issue refers to marketing practices. Iles and Marsh (2012) consider that supply chain and marketing conditions may limit the ability of farmers to adopt sustainable practices, especially as regards crop diversity. Many studies have dealt with short marketing channels, such as local markets and box schemes, which strive to minimize the stages between production and consumption (Renting et al. 2003). Most of them focused on the relationships between the various stakeholders at a territorial level. As the organic sector has evolved in the past 20 years from a niche to mass market, longer marketing channels gained significant market share in organic products (Buck et al. 1997). In a previous study in South East France, we analysed how farmers' marketing decisions affect and are linked to crop management decisions (Navarrete 2009): vegetable farms engaged in short marketing channels had to crop a wide range of products and therefore built large crop rotations, which is supposed to be favourable for natural pest regulation. In contrast, most farmers selling through long marketing channels adopted a mass production strategy based on few high-profit crops and, as a consequence, on very narrow crop rotations, even after conversion to organics. Similar results were observed by Bacon et al. (2012) in California. Beyond the binary distinction between long and short channels, Ilbery et al. (2010) identified in England an increasing trend towards hybridization, which is the combination of various channels at the farm level. Moreover, marketing not only depends on farmers' individual strategy, but also on collective dynamics among farmers and social actors involved in the territorial agrifood system (Lamine et al. 2013). Bacon et al. (2012) even consider that the agro-ecological principles can, in the absence of supportive institutions, give way to conventional supply chain management. In this study, we analysed how diversified organic farms tackle the 
question of marketing and to which extent the combination of varied marketing networks (long and short channels; various outlets) is a way to increase farm sustainability.

Therefore, the first aim of our study was to explore the multi-dimensional issues of crop diversification in organic vegetable farms by comparing farm management in diversified and specialized farms. The second aim was to analyse their sustainability. Sustainability is often assessed on a set of indicators which characterize its ecological, economic, and social dimensions (Van Cauwenbergh et al. 2007, Pelzer et al. 2012, Collomb et al. 2013, Liu and Zhang 2013). Such methods usually calculate an overall sustainability grade by summing the criteria (possibly after weighing each criterion), but do not explain how the various dimensions of sustainability and criteria interact at the farm level and how they could be adjusted altogether. Other studies propose holistic frameworks to take into account the various factors affecting sustainability (Lopez-Ridaura et al. 2002, Ripoll-Bosch et al. 2012) in a dynamic way, for instance, with the concept of resilience (Darnhofer et al. 2010) or flexibility (David et al. 2010). Our aims were to understand the synergies or competitions between sustainability criteria and to assess how the various farm management components contribute to the farm sustainability. It was also to analyse the capacity of farms in becoming more sustainable rather than categorizing the present state of the farms studied.

We assume that the relationships between the social and agronomic issues of diversification partly depend on farm size. In vegetable production, medium and large farms usually specialize in a few species in light of the economy of scale, whereas small farms are often engaged in diversification, which is considered a safer strategy for limited surface areas (Smukler et al. 2008, Bacon et al. 2012). In France, the first vegetable farms that converted to OF during the last few decades were mainly small-scale, diversified, and engaged in local selling networks ( $82 \%$ of the market-garden farms, Agence Bio 2010). But the future development of organic vegetable production probably relies on promoting the conversion of medium and large farms. We assume a non-mainstream point of view in this regard, paying attention to the way such farms can contribute to the sustainability of the territories in which they are located. Therefore, the study also aimed at understanding how medium and large farms can cope with crop diversification.

\section{Methods}

\section{The case study}

The study was conducted in the highly productive horticultural region of Provence Alpes Cote d'Azur (PACA) in the south of France, which is the first French region with organic production; $12.3 \%$ of the usable agricultural area was devoted to organics (in 2011). The site was chosen as a case study for two main reasons: the simultaneous presence of specialized and diversified farms on the same area and the diversity in marketing channels. First, conventional vegetables are produced in very intensive crop rotations, combining long summer fruit crops and short winter leafy crops. They use high levels of chemical products and nutrients. Part of the organic farms remains specialized after conversion while others move towards more diversified farming systems. Therefore, the case study is well adapted to analyse the implications of crop diversification. Second, as regards marketing networks, the area was originally devoted to supply long channels (French and foreigner distributors) with 'primeurs'. This outlet remains very active for organic vegetables, because of the warm climate and the presence of plastic shelters which enable to produce early vegetables. But there is also a large demand of local urban areas for organic products. It is therefore well-suited for studying how farms mobilize a diversity of outlets and networks. 


\section{Data collection}

The study was based on joint social and agronomical surveys of 30 organic farms combining market-garden productions and other traditional productions of area (orchards, vineyards, and cereals) (Jean 2011, Marguerie 2011). In this area, organic farms, as well conventional farms, almost never combine crop production and animal husbandry, despite it being advisable for organic plant nutrition. The other forms of diversification, including farming or non-farming activities (Zander 2008), were not considered. The farm sample was chosen to represent the diversity of farms within the regional population in regards to surfaces devoted to vegetables (from 0.5 to 14.5 ha, 4.4 ha on average), cropping systems (from 2 to 22 vegetable species, 10 on average), and marketing systems. The interviews were semi-structured in order to collect both quantitative and qualitative data. We characterized farming systems, labour organization, and marketing outlets with factual data but also examined farmers' reasons for the current situation and dynamics since conversion. The three topics were questioned as follows. (i) Cropping systems were described by their surface areas, the species cropped, their temporal organization, and the crop technical management. Pest and disease management was recorded in more detail because it is a major bottleneck of market-gardening, even more so in OF: use of green manure, organic amendment, soil thermal disinfestation, natural antagonists, etc. (ii) The various marketing channels were characterized: percentage of vegetable production volumes sold for each of them, quality requirements. (iii) Information on labour consisted in the number and types of workers, qualification of the tasks realized, quality of the work, labour organization. For the farms having a direct selling activity, we also characterized it with details because it is time-consuming and competing with farming activities. Part of the interview was based on open questions to understand how marketing and labour issues influence, and are linked to, farming practices. Particular emphasis was placed on the specific requirements of crop diversification (e.g. knowledge and skills, hired and familial work, crop management, engines, equipment, and market). We also questioned the farmers about the main difficulties they faced in the long term, before and since conversion to organics, and the solutions they had found to at least limit these difficulties. Interviews varied in length from 1.5 to $3 \mathrm{~h}$ and were recorded.

Although farm sustainability is usually described with a large list of attributes (Pelzer et al. 2012), we focused on a few indicators of sustainability that were relevant for analysing crop diversification in market-gardening. We concentrated on pest and disease issue for the agronomical dimension of sustainability, on marketing issue for the economic one, and on labour issue for the social one. For each dimension, several criteria were used (Table 1). They were estimated from the data collected during the interviews (an example of this expertise process is given on Table 1).

\section{Data analysis}

We first built an a priori farm typology based on the surface area devoted to market-gardening and the number of vegetable species cropped each year on the farm. We hypothesized that these variables are relevant for analysing how market-gardeners cope with crop diversity. Then, for each of the four farm types, we compared the farming systems, marketing networks, and labour organization between farms and we identified farm characteristics and strategies that were common within a type. Statistical analysis was performed using R software for quantitative data (analysis of variance with the vegetable surface area and the degree of diversification as factors). In a second stage, the sustainability of the four types was analysed on a qualitative way based on the criteria indicated on Table 1. The third stage consisted in discussing innovative organizations 
Table 1. Criteria used for assessing sustainability in the study and literature references.

\begin{tabular}{|c|c|c|c|}
\hline $\begin{array}{l}\text { Sustainability } \\
\text { dimensions }\end{array}$ & $\begin{array}{l}\text { Main component as } \\
\text { regards } \\
\text { diversification }\end{array}$ & Criteria & References \\
\hline Agronomical & $\begin{array}{l}\text { Pest and disease } \\
\text { control }\end{array}$ & $\begin{array}{l}\text { - Cropping systems are close to the } \\
\text { 'Redesign' level in ESR grid } \\
\text { - Preventive practices for controlling pests } \\
\text { and diseases are favoured (increasing } \\
\text { planned biodiversity, enhancing natural } \\
\text { enemies development...) } \\
\text { - Crop return time is lengthened } \\
\text { - Crop rotations take into account the } \\
\text { - Alternative techniques such as green } \\
\text { manure or solarization are regularly used }\end{array}$ & $\begin{array}{l}\text { Hill et al. (1999) } \\
\text { Hill and McRae } \\
\quad(1996)\end{array}$ \\
\hline Economic & Marketing channels & $\begin{array}{l}\text { Marketing channels are chosen for: } \\
\text { - Ensuring a satisfying and stable farm } \\
\text { income } \\
\text { - Reducing the dependence to buyers } \\
\text { - Avoiding cash shortfalls } \\
\text { - Creating economies of scale }\end{array}$ & $\begin{array}{l}\text { Iles and Marsh } \\
\quad(2012) \\
\text { Navarrete (2009) } \\
\text { Renting et al. } \\
\quad(2003) \\
\text { Van Cauwenberg } \\
\quad \text { et al. }(2007)\end{array}$ \\
\hline Social & Labour & $\begin{array}{l}\text { - Sufficient skills and knowledge are } \\
\text { available on farm } \\
\text { - Workload on farm is acceptable } \\
\text { - Work satisfaction for farmer and workers } \\
\text { is increased (rewarding professional } \\
\text { experience, interest for the work, social } \\
\text { acknowledgment) } \\
\text { - Contribution to employment }\end{array}$ & $\begin{array}{l}\text { Buck et al. (1997) } \\
\text { Darnhofer (2005) } \\
\text { Dufour et al. } \\
\quad(2010) \\
\\
\text { Dupré et al. } \\
\quad \text { (2012) } \\
\text { Escalante and } \\
\text { Santos (2010) } \\
\text { Jansen (2000) } \\
\text { Nettier et al. } \\
\text { (2012) } \\
\text { Rickson } \text { et al. } \\
\text { (1999) }\end{array}$ \\
\hline
\end{tabular}

Notes: Examples of the expertise process: A farm cropping only three vegetable species each susceptible to the same pest (e.g. root-knot nematode) with a return time of susceptible crops shorter than two years and introducing commercial biological agents on each crop as if it was a chemical treatment belongs to the Substitution level and has a low agronomic sustainability. A farm cropping more than 10 vegetables with a longer crop return time but without choosing crop succession for limiting pest and control species has an intermediate sustainability, lower than one in which cash crops and green manure crops are organized in priority to alternate host and non-host species. In ESR grid (Hill and McRae 1996), 'Redesign' level consist in reorganizing production systems according to ecological principles; 'Substitution' level in replacing one measure by an alternative one.

that could increase sustainability and foster conversion to organic production, both at the farm level and at the territorial level: it was either innovations expressed by farmers during the interviews, already implemented on their farm or still in project, or a proposal of the scientists deriving from the analysis of the survey. 


\section{Results}

\section{General overview of the sample}

As indicated previously, the four types of farms come from the combination of two variables, the number of vegetable species cropped yearly and the surface area devoted to market-gardening (Figure 1). Thirteen farms in the sample specialized in a limited number of vegetables (range $3-8$ ). Type Spe/S consisted of farms with a small (S) vegetable area (2 ha on average) in only open fields, growing 3.4 vegetable crops per year on average. Market-gardening was a minor activity compared to orchards, vineyards, or cereal crops. The other type (Spe/L) consisted of farms that had a larger vegetable area (on average 9.5 ha including 1.3 ha of shelters), with 6.5 vegetable crops on average. Market-gardening was the major economic activity (as regards percentage of income) although most of them also grew large amounts of fruit, grapes, or cereals. Seventeen farms in the sample had much more diversified vegetable production, with 10-22 species in open fields and under shelters. Div/S type farms had a small surface area for vegetables (2.3 ha) and grew the highest number of vegetables in the sample, with an average of $14.3 \mathrm{veg}$ etable species. Half of the farmers grew only vegetables, and the others combined the vegetables with fruit and grapes. Div/L type farms grew vegetables on larger areas (about 10 ha) and were as diversified as the previous type with 13.2 vegetable species on average. The differences between the four farm types were significant for the number of vegetable species and the surface area (Table 1).

Several types of marketing were observed in the area (Figure 2) that differ in the quality requirements, the period, and frequency of supplying, the expected range of vegetables, and the level of engagement with customers. When involved in long channels, farmers sold vegetables to either wholesalers (French or export outlets) or cooperative organizations. Long channels, especially for export, had nearly the same requirements as in the conventional sector (i.e. no

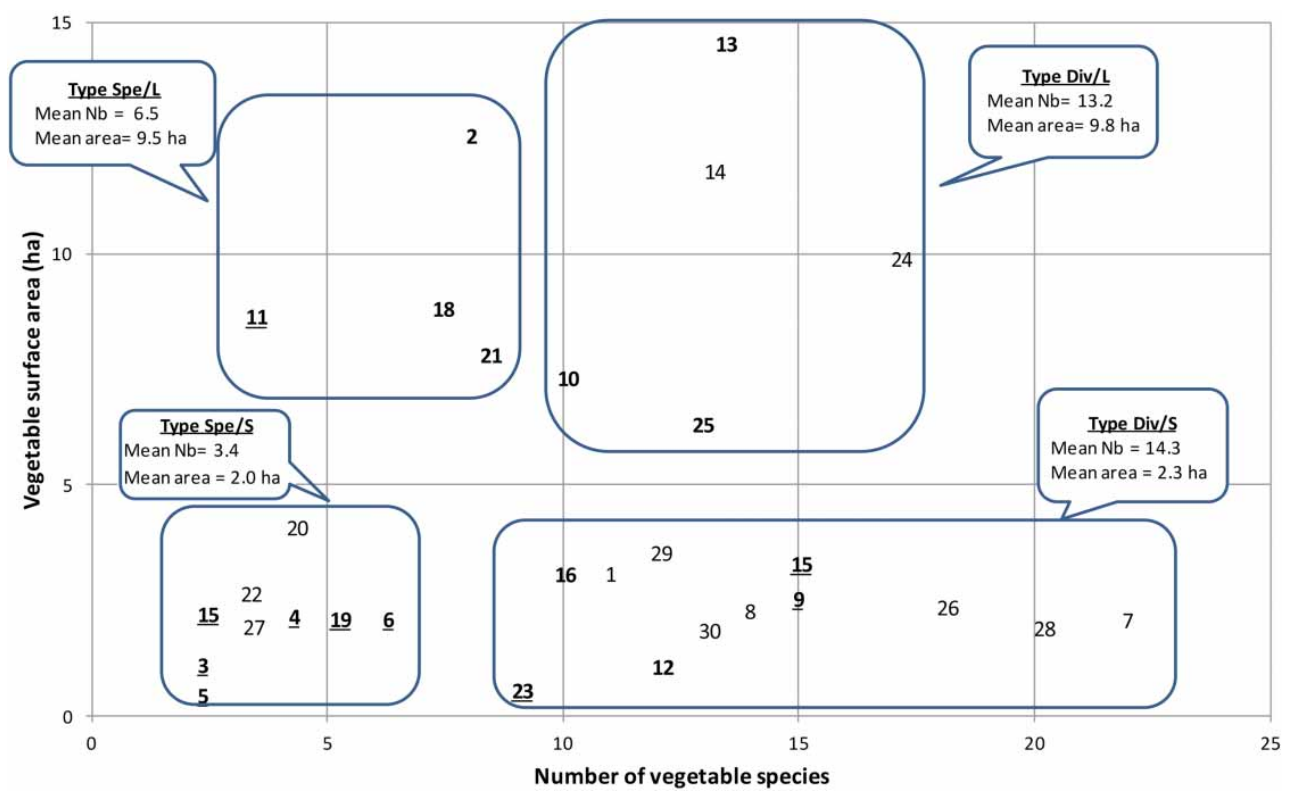

Figure 1. Typology of the diversification of organic market-garden farms surveyed in PACA region. The figures indicate the numbers of the farms surveyed. Surface for non-vegetable crops: bold underlined, more than 6 ha; bold, 2-5.9 ha; normal, no other crop. 


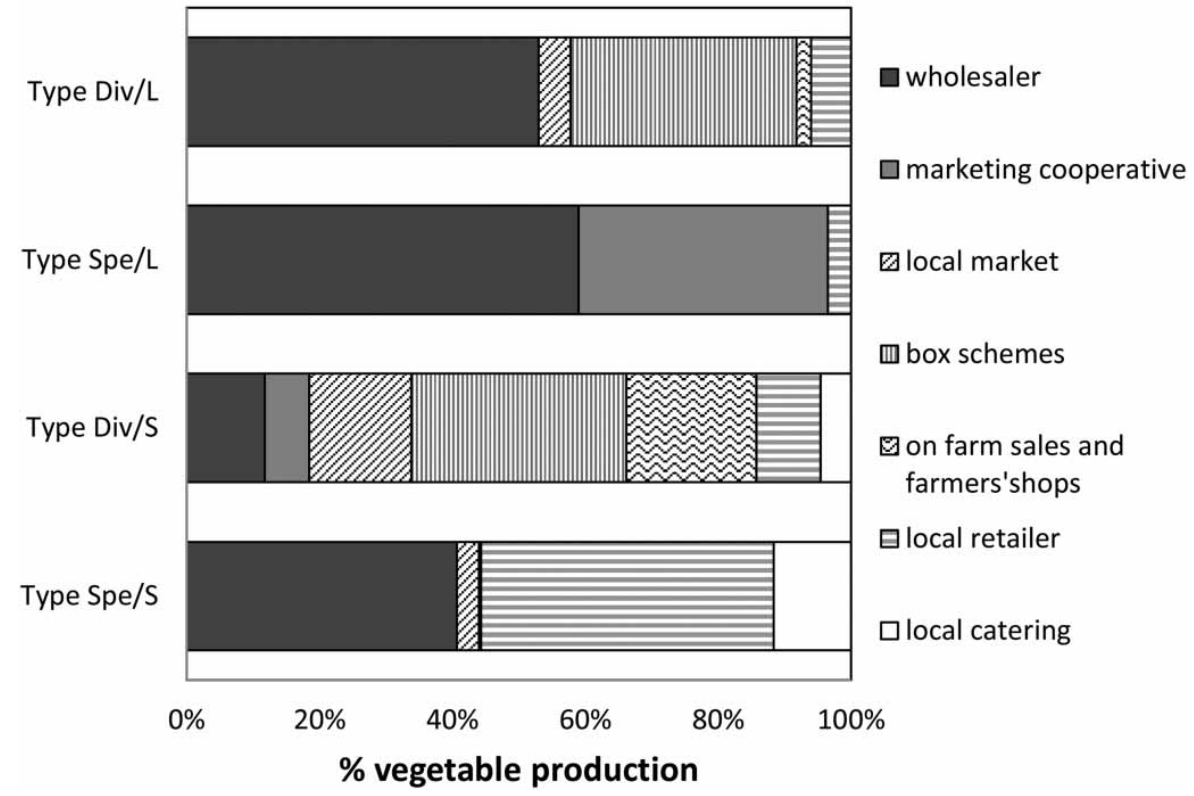

Figure 2. Allocation of vegetable production among the different marketing channels for each type of farm. The $\mathrm{X}$ variable indicates the percentage of the yearly vegetable production sold to each type of marketing network (data from farmers' accounting).

disease spot, homogeneous grades or colours), but the advantage for the farmers was that they did not have to package vegetables. As regards short channels, we distinguished those where farmers directly interact with consumers and those where they are in relation with middlemen. The first category includes open-air markets, box schemes (where the farmer is committed to provide a weekly box of vegetable for a group of consumers on an annual basis) and on-farm selling. Farmers had to crop a diversity of products and spent a lot of time packaging and selling the products, which often competed with the farming activities. The second category consists of selling vegetables to a local retailer, or for local catering (especially for schools or restaurants); farmers cropped fewer vegetables and spent less time in marketing than when they directly sold to consumers.

We now successively describe how crop management, marketing outlets, and labour interact in farms with specialized and diversified vegetable production and analyse their sustainability in a systemic and dynamic way.

\section{Farm management and sustainability of specialized farms}

\section{Farm management}

In farms specializing in a few vegetable products (types Spe/L and Spe/S), crop rotations were very narrow because of the limited number of vegetables. The species mainly belonged to four plant families: Solanaceae (tomato, eggplant, potato, and sweet pepper), Cucurbitaceae (zucchini, pumpkin, and melon), Asteraceae (lettuce), and Brassicaceae (cabbage). The crop return time, that is the period between two successive plantings of a species on the same plot, was 1-2 years. Most farmers surveyed were fully aware that the current crop rotations increase soil-borne disease risks, and they used several practices to reduce them. Some of them introduced cereals in the vegetable open-field rotation, which are non-host of the major vegetable diseases (6 farms out of 13). Others cropped green manure (10 farms out of 13), to increase soil organic matter and create a cycle 
break for soil-borne pests if selecting a non-host species (such as Phacelia or Brassicaceae for root-knot nematodes). But in the sample, sorghum was the main species planted under shelter; cereal and legumes were preferred in open fields. Green manure crops could be easily introduced into these specialized farms because the plots were free in the summer and could afford a 2-3 month non-commercial crop.

All the specialized farms of the sample were jointly run by several members of a family, and were the most experienced in farming and organics within the sample, with an average of 19 years since conversion. Despite the availability of an important and permanent familial task force, labour organization depended on the size of the vegetable activity. In type Spe/S farms, work was mainly realized by the familial work force; only one farmer employed a permanent worker. For time-consuming tasks such as harvesting, seasonal workers or students were used. But when the vegetable area was larger (type Spe/L), one to three permanent and seasonal workers were hired (most of them being local workers rather than migrant).

In regards to marketing (Figure 2), specialized farms sold their products in long or short channels, depending on the surface area, but never directly to consumers because of lack of diversity. The percentage of vegetable production sold to long channels significantly depended on the degree of diversification and the size of the vegetable area (Table 2). Small farms (type Spe/S) sold approximately $41 \%$ to long channels; the majority (59\%) was sold to local outlets, including box scheme providers that they complemented, or restaurants. Few of them could afford selling on long channels, which require larger amounts of product. But they often combined short and long channels. Farms with larger surface areas (type Spe/L) sold $96 \%$ of their vegetables in long marketing channels, to several sellers in order to increase their financial security $(63 \%$ of production to wholesalers and $30 \%$ to co-operative organizations). Only $4 \%$ of the production was sold locally, usually a few seasonal vegetables that were highly profitable.

\section{Empirical assessment of sustainability in specialized farms}

On such specialized farms, the agronomic sustainability based on the criteria listed on Table 1 remains low because crop management does not differ drastically from that of conventional production on the same area (Navarrete et al. 2006), except for the banning of chemical treatments. Hence we consider the organic practices in these farms as being closer to the Substitution level than to the Reconception level of the ESR grid. Farmers use biological treatments in a curative

Table 2. Comparison of the four farm types.

\begin{tabular}{|c|c|c|c|c|c|c|}
\hline \multirow[b]{2}{*}{ Variables } & \multicolumn{4}{|c|}{ Farm types } & \multicolumn{2}{|c|}{ Statistical test (proba) } \\
\hline & Spe/L & Spe/S & Div/L & Div/S & $\begin{array}{c}\text { Diversification } \\
\text { effect }\end{array}$ & $\begin{array}{l}\text { Size } \\
\text { effect }\end{array}$ \\
\hline Number of vegetable species & $6.5 \mathrm{a}$ & $3.4 \mathrm{a}$ & $13.2 \mathrm{~b}$ & $14.3 \mathrm{~b}$ & $<0.001^{* * *}$ & 0.618 \\
\hline Surface area for vegetables (ha) & $9.53 \mathrm{a}$ & $1.97 \mathrm{~b}$ & $9.80 \mathrm{a}$ & $2.26 \mathrm{~b}$ & 0.661 & $p<.001^{* * *}$ \\
\hline Mean return delay (years) & $1-2$ & $1-2$ & $4-5$ & $3-4$ & / & / \\
\hline Frequency of cereals & $2 / 4$ & $4 / 9$ & $1 / 5$ & $2 / 12$ & / & / \\
\hline $\begin{array}{l}\text { Frequency of green manure } \\
\quad \text { or solarization }\end{array}$ & $3 / 4$ & $7 / 9$ & $3 / 5$ & $2 / 12$ & / & / \\
\hline$\%$ production sold to long channels & $96.3 \mathrm{a}$ & $40.7 \mathrm{a}$ & $53.0 \mathrm{~b}$ & $18.4 \mathrm{~b}$ & $0.0370^{*}$ & $0.0041^{* *}$ \\
\hline$\%$ production sold to box schemes & $0 \mathrm{a}$ & $0 \mathrm{a}$ & $34.0 \mathrm{~b}$ & $32.3 \mathrm{~b}$ & $0.0151^{*}$ & 0.9761 \\
\hline
\end{tabular}

Notes: Statistical test: analysis of variance with two factors representing the a priori typology (Size: small or large farms; Div: Diversified or specialized farms). For each significant effect, asterisks denote significant effects $\left({ }^{* *}<.001 ;{ }^{* *}<.01\right.$;

$*<.05)$. Mean values followed by the same letter are not significantly different according to the Tukey test. 
way, as several antagonists are available especially for sheltered crops. Crop rotations are very narrow, even if green manure or cereals are introduced as diversification. The crop return time is much shorter than what plant pathologists advise for avoiding pest risks. For example, most of the species planted are hosts of root-knot nematodes (Meloidogyne spp.), a worrying disease in the area. Thus, the cropping systems are quite risky from a sanitary point of view, especially for soil-borne pests. Once soils are colonized by pests, organic farmers hardly have any ways to remediate them (Collange et al. 2011). The last possibility is moving crops away from the colonized plots into healthy plots, which depends on land reserve on farm, hence on the total usable surface area.

As regards economic sustainability, the risks of specialization in vegetables are compensated for by the other crops, such as cereals, fruits, or grapes. Not only does the combination contribute to spreading the work over the whole year, but it also guarantees stable income all year long and makes employing a permanent worker possible. The combination of several outlets in long channels, or of short and long channels, is also a way to secure farm income: long channels are used for disposing of large amounts of standardized products and short channels for specific products and sometimes products with visual defects. As short channels require a diversity of products, it could be used as a way to enlarge the crop rotations in large farms combining short and long channels. Surprisingly, in our sample, the short/long combination did not enable an improvement of the agronomical sustainability because the land was usually divided into two parts, one highly diversified and dedicated to the short channel, and the other specializing in a few vegetables for wholesalers. The main reason was that the cultivars and crop managements were specific to each outlet (long shelf life cultivars for wholesalers or export; diversified colour and tasty cultivars for short channels). So the outlet requirements reduced the room for manoeuvring crop rotation to prevent soil-borne pathogens.

Considering the labour issue and social sustainability, specialized farms of the sample are based primarily on a familial task force on small farms. The lack of permanent hired work force is compensated by occasional workers and/or a high level of equipment. For both specialized types of the sample, farmers never considered labour force as limiting; cropping decisions and labour organization seemed to be well suited to each other.

As a conclusion, specialized farms have a rather industrial organization of labour and marketing and benefit from economy of scale. But in the long term, they may suffer from low agronomical sustainability because of the limited number of species cropped and crop management, even if farmers were able to use alternative techniques (solarization, green manure) to control soilborne pests.

\section{Farm management and sustainability of diversified farms}

\section{Farm management}

The farms cropping a large number of vegetables (Types Div/S and Div/L) cropped a significant higher number of vegetables (Table 2) and had larger crop rotations than the specialized farms, with a longer crop return time (3 years or longer). Cereals were rarely combined with vegetables in rotation (only 3 farms out of 17). When the land devoted to vegetable was limited (type Div/S), growers rarely used green manure or soil solarization (only 2 out of 12) to control soil-borne diseases. First, they counted on natural regulations favoured by crop biodiversity rather than using alternative techniques. Second, land and time were rarely available in the summer because they gave priority to commercial crops. Unlike the previous type, when vegetable surfaces were larger (Div/L type), the return time for a particular species was about 4-5 years in open fields, and shorter under shelter because of the limited surface area. Farmers were able to lengthen the 
intercrop period between two commercial crops and to plant green manure (3 farms out of 5). From time to time, these farms even suppressed a commercial crop on a particular plot as fallow land, which was impossible on smaller farms. The design of crop rotations was therefore much easier in Div/L than in Div/S type farms.

Labour requirements per hectare of vegetable crops were much higher than in specialized farms. In Div/S farms, labour mainly relied on occasional workers, and more often on neigbours' or friends' help. As most farmers of the sample started the agricultural activity in the 2000s, they were not able yet to financially handle hired labour. In Community-Supported Agriculture (CSA) box programmes, consumers could take charge of some tasks, such as the weekly delivery of the products and the administration of contracts, and might sometimes help on the farm, as instance for removing a shelter. When vegetable area was larger (type Div/L), permanent workers were hired, especially to perform the numerous year-long cultivation practices under shelters. Farmers considered diversification as a more complex, time-consuming, but enjoyable activity. Diversification increased complexity in planning crop organization and calendars because they had to take into account crop requirements and plot agronomical constraints, while optimizing land use and labour at the farm level. On a day-to-day basis, diversification required an everyday presence on plots in order to check crops and provide a relevant and quick technical response to every problem. Some tasks were never delegated to hired workers, especially irrigation for at least two reasons. First, farmers preferred to tackle themselves the complexity of irrigation due to the simultaneous presence of several crops on a piece of land. Second, handling irrigation allowed them to personally watch over the crops, constituting a very strategic activity. At the same time, everyday activity was more attractive and less monotonous for both the farmers and the workers. It was more rewarding because they had to acquire a broad range of skills and knowledge on various crops, to identify various pests and diseases.

Marketing significantly depended on the vegetable surface area (Table 2). When it was limited (type Div/S), short channels were by far the main outlet (82\%), with box schemes comprising $25 \%$ of the amount of vegetables sold. The $18 \%$ of vegetable devoted to long channels corresponded to selling one particular vegetable in a large quantity to a wholesaler ( 3 farms out of 12). When the vegetable area was larger (type Div/L), farmers could not afford to only sell on short channels, except for two in the sample who combined two to three box scheme organizations. Thus, $53 \%$ of the products were sold to wholesalers. The relationship with consumers was most often described as more rewarding and farmers could have a direct feedback on production. But direct-selling required a lot of time for cleaning, sorting, and packaging vegetables all the more as this task was never delegated to a non-familial worker, but rather to wives and daughters. Some farmers in our sample preferred box schemes because the work could be planned more easily. But it required cropping a diversity of vegetables throughout the year (at least five or six each week); crop organization had to be strictly planned throughout the year. For key species, such as lettuce and tomatoes, several planting dates and cultivars were combined, on open-field and under shelters, in order to lengthen the harvesting period up to $6-8$ months. The complexity of planting patterns explains why inexperienced farmers had difficulty in box schemes and preferred open air markets or on-farm selling, where they do not have to commit to consumers for a whole year.

\section{Empirical assessment of sustainability in diversified farms}

From an agronomical point of view, the higher functional biodiversity, the more sustainable cropping systems are. Thus we now discuss whether diversified farms are more sustainable than the specialized farms described previously. On the diversified farms of the sample, most crop rotations were driven by marketing requirements. Most farmers did not take into account the 
fact that some species are hosts of the same pests, such as Cucurbitaceae and Solanaceae for rootknot nematodes. Few farmers tried to build crop rotations based on the optimization of soil nutrients and soil-borne pest control, in addition to marketing requirements. For example, they combined large crop rotations and the cropping of non-host botanical families as cash crops or green manure in order to increase cropped biodiversity and counteract pest cycles. This refers to the Redesign level in the ESR grid. It is important to notice that the room for manoeuvre for redesigning crop rotations in short-channel farms is all the larger as the surface area for vegetable represented a limited percentage of the total usable area, and/or that enough surface area was available for vegetable on farm, in particular under plastic shelters. Anyway, despite difficulties in building efficient crop rotations in most diversified farms, a positive point is that the agronomical risks (pests, diseases...) are spread over several crops, plantings, and plots.

As regards social sustainability, work intensity increases in diversified farms due to the simultaneous presence of several crops to manage on the farm, but farmers declared it is partly counterbalanced by an increase in work satisfaction of running the farm in a more interesting and challenging way. This is probably why farmers said they were not overwhelmed, although the number of workers was limited compared to the diversity and number of tasks to be realized. Direct selling contributed to a professional pride and helped them better cope with their additional work on the farm. Moreover, as diversification requires more labour, especially for direct selling, family members are often heavily involved. These workers and helpers create work flexibility and guarantee the farm sustainability. While some farmers in our sample considered crop diversification as a technical challenge, others who were less experienced or more vulnerable emphasized the difficulties and risks of failure, stress, and exhaustion, especially when consumers criticized the vegetables and expressed their dissatisfaction. The latter position is more specific to farmers who either converted to organic production after a very short experience in conventional marketgardening or had not look ahead to prepare technical changes before conversion. Therefore they had difficulties in building complex crop rotations.

From a marketing point of view, such farms appear to be quite secure thanks to short channels: farmers could reach higher margins than with long channels; they could stabilize farm income (especially with box schemes) and provide cash money throughout the year, whereas cash inflow in specialized long-channel farms was very season-dependent. From an ethical point of view, farmers considered direct selling as being more consistent with the values of organic agriculture. But the small-scale farms, which represent the largest proportion of diversified farms, suffer from a limited source of income and increase in equipment costs because some crops require specific planting or harvesting equipment.

Analysing farm dynamics also gives information on how farmers try to find a more sustainable farm management. For instance, some diversified farmers of the sample initially experienced a very complex organization of crops and labour when converting to OF, which often generated stress and lots of work. Two simplification trends were identified in our sample. (1) Some farmers simplified crop management and farm functioning without limiting the species range. For example, when several species were grown simultaneously on a same plot, they did not adapt water or fertilizer amounts to each species; they sometimes renounced a particular treatment if it was not adapted to the next crop. Some of the farmers delegated some tasks to agricultural enterprises, such as tillage or plant nursing. (2) Other farmers reduced the number of species cropped, which is a kind of re-specialization (without ever reaching the degree of what we called specialized farms). In particular, they said that species that require too much work were often excluded (e.g. strawberry, spinaches, peas, lentil), as were those for which special equipment was needed (e.g. leek or potatoes). Another adaptation trend was observed in regards to labour force. Whenever they could, farmers managed diversification by trying to retain their seasonal, hired workers as long as possible. For example, they introduced precocious and late varieties to stagger the 
harvest period in order to secure labour force, as regards both the number of workers and their skills.

As a conclusion, diversified farms appear to be more sustainable according to the social and marketing dimensions, although such farms regularly suffer from severe workloads. But these farmers fail in optimizing crop rotations and management for agronomical reasons because of the weight of direct marketing requirements in cropping decisions. The simplification trend often observed in the most complex cropping systems after a few years reveals the difficulty in determining an optimal degree of crop diversification.

\section{Discussion}

This study aimed at analysing various farm types and assessing how their characteristics contribute to their global sustainability and how the several components of sustainability interact at the farm level. In the following discussion, we will address the three dimensions specifically studied, that is, crop management, marketing and labour issues, by referring to international literature, and we will point out some innovative forms of organization on the farm and territorial levels that could increase farm sustainability.

The four types of farm were relevant to explain the overall diversity in the sample. Significant differences were observed between them. Our typology, although less detailed, is also coherent with another one built on the same area (Bio de Provence 2012). This report indicates 7 types of farm differing with the surface area and the marketing channels, among which 4 types are quite similar to ours: specialized farms with less than 10 species and selling to long channels (equivalent to Spe/L type); farms mainly involved in long channels with intermediate degree of diversification (equivalent to Spe/S), very diversified farms with small areas (Div/S) or larger areas (Div/L). The report also distinguished sub-types depending on the origin of farmers (coming from a farmer family or neo-rurals) and the length of time since conversion to organics. Anyway, the thresholds for the key variables of both farm typologies (surface area and number of species) slightly differ, which confirms that our study must be seen as a qualitative contribution to the diversification issue rather than a quantitative one.

We confirmed the tight relationships between marketing and production systems on horticultural farms, with the distinction of specialized farms engaging in long marketing channels and diversified farms selling in short channels, as previously reported (Buck et al. 1997, Renting et al. 2003). But beyond this dualistic representation, we found a spectrum of variation within each. Several combinations are promising. We observed an efficient association between long and short channels, which is a good way to adapt the marketing outlets to the actual quality produced on the farm and to secure outlets and incomes. The diversified as well as the specialized farms combined a major outlet with a minor one. Sorting vegetable production on actual quality at harvest and adapting in real time the array of outlets was a strategy to improve the global margin. Such a combination of outlets and hybridization of marketing channels at the farm level was observed previously (Navarrete 2009). Ilbery et al. (2010) also made an interesting distinction between occasional arrangements, such as when local producers use long channels to dispose of the farm production surplus, and more permanent arrangements in order to not be overly dependent on just one outlet. But in this study we showed that the specificity in cultivars and crop management often limits the room for manoeuvre, because the different products were not interchangeable. Moreover, another form of diversification consisted in combining marketgardening and other crops, which refers to 'horizontal diversification' as a way to secure farm income (Zander 2008). In our study, cereals and vegetables were cropped in rotation on the same plots to limit pest risks. Other farmers combined vegetables and orchards at the farm level in order to maintain a permanent skilled labour force throughout the year. 
A key question to increase farm sustainability refers to how crop rotations could be optimized on an agronomical point of view, since they are mainly chosen according to marketing requirements. Additional studies would be necessary to help farmers use diversification as an agronomic lever, not only for filling the gap in agro-ecological knowledge, but also on designing crop rotations. First, a better characterization of the ecological functions of the species cropped, and more generally of the biodiversity, is required, in particular in regards to their potential role in soil health (Swift et al. 2004). Hence, it would be possible to foster natural regulations in crop rotations and cultural practices (Zehnder et al. 2007, Collange et al. 2011). Second, it would be interesting to build a tool for helping farmers to optimize organic cropping systems for crop production and resource as highlighted by Smukler et al. (2008), and more specifically to design crop rotations taking into account both marketing and agronomical constraints. There is a first attempt with the ROTAT model (Dogliotti et al. 2005). The model enables to optimize temporal interactions in crop rotations in vegetable farms by taking into account both economic issues (maximizing family income and gross margin) and environmental issues (minimizing soil erosion and improving physical and biological soil fertility). But the model underestimates the complexity of labour issue since the only social criteria taken into account is labour requirements per crop. According to Smukler et al. (2008), another challenge is to decide plot or planting sizes both for increasing ecological functions and maintaining an economy of scale that increases profits, especially in medium and large farms. Few studies tackle the question of crop diversification on larger vegetable farms. In the Salinas Valley, California, they described transition of large farms towards organics. Farmers first decided to crop a large number of species in small plantings at staggered intervals, for avoiding risks from low yields or crop failure. But after the transition period, they moved towards a smaller number of successful crops in order to be more efficient. In another French production area, Lamine (2011) identified a general trend towards simplification of crop management or reduction in crop diversity to simplify cropping patterns and labour organization. The process was usually carried out following an extension of the surfaces and development of mechanization.

Moreover our results give a broad analysis on the labour issue in market-gardening. We showed that it relies not only on the availability of labour force and skills at the right time, but also on the psychological dimension of labour (satisfaction, mental workload, etc.). These issues have been often addressed by sociologists studying the organic sector, but never comparing diversified and more specialized farms. Salmona (1982) noted that crop organization and crop calendars in very diversified systems require efficient know-how and experience before being efficient and stabilized, all the more as a lot of species are cropped. The importance of timing and scheduling is also noted by Jansen (2000) and Paturel (2010); in OF the preventive or curative measures for weeding or controlling pests have to be done in right time because their efficiency largely depends on when it is used. 'To achieve these goals,' insists Jansen, 'more labour may be required, in the sense of managing this timing, and carrying out more small tasks instead of one larger task' (Jansen 2000, p. 258). In our sample, diversified farmers found the job more challenging and pleasant thanks to the numerous crops and plots. This result is in agreement with many studies (Tovey 1997, Darnhofer 2005, Bon et al. 2012). Rickson et al. (1999) found that Australian organic farmers thought they had developed more control over their work, that they were working more in harmony with nature, and felt more environmentally competent. Satisfaction at work in organic farms could compensate for the heavier workload (Dupré et al. 2012, Nettier et al. 2012). In market-garden farms engaged in short channels, Bon et al. (2012) distinguished two points of view on labour, even if they are partly combined in most farms: one based on personal satisfaction and ethic, the other on economic and technical efficiency. The challenging dimensions of diversification expressed by some farmers in our sample rather refers to the first one, while the simplification trend observed in some diversified farms rather refers to the 
second one. Sociologists also pointed out the need for acquiring a broad range of skills and knowledge to manage crops in OF (Dufour et al. 2010, Bon et al. 2012). Thompson (1995) considers that soil functioning, in particular, is complex and that a long time is required to 'learn' it and understand how it works and what it needs. Early detection of pests and diseases in the crops, partly delegated to hired workers, is essential in OF since few curative techniques are available. This is why some farmers try to stabilize know-how on the farm and reduce the precariousness of employment and the uncertainty of recruitment, as highlighted by Shreck et al. (2006).

Hence, we have to very carefully weigh the pros and cons of crop diversification. Even if it generally increases farm sustainability in organic market-gardening, it may also weaken some farms depending on their size, labour force, or marketing networks. On the contrary, we identified some rather specialized farms that built quite interesting crop organizations without evolving to the case of mass production export-oriented farms. And yet, Hall and Mogyorody (2001) noted few signs of conventionalization in Ontario vegetable farms, as regards the size and degree of specialization. Quite similartos our results, they found a diversity of farms, comprising a large majority of diversified vegetable small farms, some mixed production farms growing field crops and one or two vegetables, and few very specialized mass production export-oriented farms. This is partly different from what was observed by Buck et al. (1997) in California, where small vegetable farms were marginalized by larger farms mimicking conventional farms as regards production marketing and labour organization. Anyway, all these studies and our results agree on the interest in taking into account simultaneously labour, marketing and cropping dimensions to estimate the sustainability of organic vegetable farms. Qualitative models such as DEXiPM (Pelzer et al. 2012) are useful tools in an optimization approach of farm sustainability; but it would be necessary to take into account the specificities of vegetable production, as those highlighted in this study.

When farm characteristics or functioning are too constraining, the collective scale may provide new room for manoeuvring to overcome the difficulties of the individual farm. When belonging to the same professional or commercial organization, farmers are involved in economic and agronomic regulations in which each farmer defines their own production, relative not only to his own constraints, but also to the market needs and other farmers' production. Being in such a network gives the farmer more opportunities to broaden their product range or buffer the irregularities of production by the exchange of products (Renting et al. 2003). But if such a transition does secure organic farms and guarantee their social sustainability through the collective dimension, pest and disease problems created by narrow crop rotations are not solved. In some alternative marketing systems, such as box schemes, producers' collective shops, and public food procurement, producers are directly involved in the definition of quality and the codification of rules, with relative freedom from classical market quality criteria (e.g. aspect, size, etc.), whereas other criteria are promoted (e.g. localness, freshness, seasonality). This redefinition of the modes of coordination and commitment often involves not only farmers, but also other actors in the territorial agrifood system (consumers as individuals, organizations, or public buyers) which provide alternative ways of adjusting offer and demand (Lamine et al. 2012). Moreover, farmers sometimes share a hired worker (e.g. through an employers' group), which is a solution to maintaining knowledge and skills on a farm, even when farmers cannot afford to employ a permanent worker. Or they rarely use mutual help. Finally the farmers sometimes exchange plots of land for a few years in order to increase the rotation possibilities, or they could lend engines (but this is limited because of the same agricultural calendar that leads farmers to resort to an equipment cooperative). Even though this study was focused on the farm level, we noticed that such relationships with other farmers or rural actors were a way to trigger or brake agricultural changes on some farms. David et al. (2010) considered that networking among organic farmers played a determining role in farm sustainability, for instance, the use 
of common specific materials (e.g. for mechanical weed control) or the joint purchase of inputs. This kind of territorial cooperation seemed to be limited in the area studied. Many farmers insisted on individualism and competition among organic farmers, especially in direct selling activities and, more generally, concerning cooperation, mutual help, and engine lending. This issue contradicts the most frequent findings that OF refers to an agrarian vision of family and community; it is probably linked to the specificity of the area studied, which is traditionally characterized by very individualist values. In other more isolated areas, stronger collective dynamics have been observed on the territorial agrifood system scale (Lamine 2012). Hence, the collective and territorial levels appear to be potential means for increasing farm sustainability, in combination with the farm levers, provided that the assets and limits of each territory are taken into account. But one limit of our results is that sustainability

\section{Conclusion}

This empirical study highlighted various forms and degrees of diversification and specialization among commercial vegetable farms and the consequences on crop management, labour organization, and marketing. The main findings refer to identifying the very complex interactions between sociological, agronomic, and economic elements, which can lead to more sustainable OF if addressed together. As recommended by Rigby and Caceres (2001), the study contributed in exploring the exact relationships between organic and sustainable farming rather than equating the two terms in a shortcut. Moreover, innovative organizations have been identified, on both the individual and collective levels, which could help farmers find equilibrium between an acceptable degree of species diversification, labour and marketing constraints, and opportunities, especially on medium and large farms. Yet, the scale of production is a very important issue because sustainable agriculture often refers to small family farming systems. We examined the conditions under which large farms can optimize the various components of sustainability, especially crop management, labour, and marketing. Our study insisted on the importance of market in the guidance of the whole system, and, in so doing, speaks in favour of a holistic approach that restores connections between production and consumption, which were partly destroyed by the industrialization of agriculture. Yet, we also determined that such a clear and desirable perspective will inevitably refer to an extremely delicate debate regarding the extension of the normalization of more, or other, criteria in order to guarantee what could be the 'genuine' organic on a territorial scale (Rigby and Caceres 2001). Such a working frame is, of course, very ambitious; it requires a very challenging and tight cooperation between various scientific disciplines (sociology, agronomy, economic, geography) and actors at the agrifood system level.

\section{Funding}

This research was supported by grants from INRA CIAB (Comité Interne à l'Agriculture Biologique) for the EPAB project, and ANR (Agence Nationale de la Recherche) for the DynRurABio project (http://www6. inra.fr/comite_agriculture_biologique/Accueil/Actualites/DynRurABio).

\section{References}

Agence Bio, 2010. La bio en France, de la production à la consummation [online]. Available from: http:// www.agencebio.org/upload/pagesEdito/fichiers/CC_Ed2011_Chap4_1_prod.pdf.

Altieri, M., 1999. The ecological role of biodiversity in agroecosystems. Agriculture, ecosystem and environment, 74, 19-31.

Bacon, C.M., et al., 2012. The social dimensions of sustainability and change in diversified farming systems. Ecology and society, 17, article no. 41. 
Bio de Provence, 2012. Acquisition de références techniques, économiques et commerciales sur le maraîchage biologique. Connaissances typologiques des systèmes maraîchers biologiques en région $P A C A, 42 \mathrm{p}$ [online]. Available from: http://www.bio-provence.org/spip.php?article1036.

Bon, N., et al., 2012. Diversité des logiques de travail dans les exploitations maraichères en circuits courts, $4^{\mathrm{e}}$ Journées de recherche en Sciences sociales, INRA-SFER-CIRAD, 1-6/03/2012, Rennes, France.

Buck, D., Getz, C., and Guthman, J., 1997. From farm to table: the organic vegetable commodity chain of Northern California. Sociologia Ruralis, 37, 3-20.

Collange, B., et al., 2011. Root-knot nematode (Meloidogyne) management in vegetable crop production: the challenge of an agronomic system analysis. Crop protection, 30, 1251-1262.

Collomb, B., et al., 2013. Stockless organic farming: strengths and weaknesses evidenced by a multicriteria sustainability assessment model. Agronomy for sustainable development, 33, 593-608.

Darnhofer, I., 2005. Organic farming and rural development. Some evidence from Austria. Sociologia Ruralis, 45, 308-323.

Darnhofer, I., Fairweather, J., and Moller, H., 2010. Assessing a farm's sustainability: insights from resilience thinking. International journal of agricultural sustainability, 8, 186-198.

David, C., et al., 2010. Long-term strategies and flexibility of organic farmers in southeastern France. International journal of agricultural sustainability, 8, 305-318.

Dogliotti, S., van Ittersum, M.K., and Rossing, W.A.H., 2005. A method for exploring sustainable development options at farm scale: a case study for vegetable farms in South Uruguay. Agricultural systems, 86, $29-51$.

Dufour, A., et al., 2010. L'herbe est-elle plus verte dans le panier? Satisfaction et intégration professionnelle des maraîchers qui commercialisent sous forme de paniers. In: Traversac, ed. Circuits courts. Contribution au développement régional. Paris: Educagri, 71-86.

Dupré, L., 2011. Travail et emploi en Agriculture biologique: désorganisation, réorganisation, transformation de la production. Premiers éléments problématiques autour du maraîchage en Paca, Colloque Ecologisation des politiques publiques et des pratiques agricoles 16-18/03/2011, Isle-sur-la-Sorgue, France.

Dupré, L., Navarrete, M., and Lamine, C., 2012. Getting more satisfaction? How species diversification and direct selling reshape labour's organization in organic market gardening. A French case study. 13th world congress of International Rural Sociology Association, 29/07-04/08/2012, Lisbon, Portugal.

Escalante, C. and Santos, F., 2010. Differentiation in farm labor complement profiles of organic and conventional farms in the southeast: Coping with a changing farm labor market, AAEA, CAES, \& WAEA joint annual meeting, 25-27/07/2010, Denver, CO.

Hall, A. and Mogyorody, V., 2001. Organic farmers in Ontario: An examination of the conventionalization argument. Sociologia Ruralis, 41, 399-322. doi: 10.1111/1467-9523.00191

Hill, S.B. and MacRae, R.J., 1996. Conceptual framework for the transition from conventional to sustainable agriculture. Journal of sustainable agriculture, 7, 81-87.

Hill, S.B., Vincent, C., and Chouinard, G., 1999. Evolving ecosystems approaches to fruit insect pest management. Agriculture, ecosystems and environment, 73, 107-110.

Ilbery, B., et al., 2010. Marketing concentration and geographical dispersion. A survey of organic farms in England and Wales. British food journal, 112, 962-975.

Iles, A. and Marsh, R., 2012. Nurturing diversified farming systems in industrialized countries: how public policy can contribute. Ecology and society, 17, article no. 42.

Jansen, K., 2000. Labour, livehoods and the quality of life in organic agriculture in Europe. Biological agriculture and horticulture, 14, 247-278.

Jean, E., 2011. Maraîchage biologique et organisation du travail: Enjeux et conséquences de la diversification. Etude de cas: Vaucluse et Bouches-du-Rhône, PACA, Engineer report AgroParisTech / Muséum National d'Histoire Naturelle, Paris, France.

Kremen, C. and Miles, A., 2012. Ecosystem services in biologically diversified versus conventional farming systems: benefits, externalities, and trade-offs. Ecology and society, 17, article no. 40.

Kremen, C., Iles, A., and Bacon, C., 2012. Diversified farming systems: an agroecological, systems-based alternative to modern industrial agriculture. Ecology and society, 17, article no. 44.

Lamine, C., 2011. Transition pathways towards a robust ecologization of agriculture and the need for system redesign. Cases from organic farming and IPM. Journal of rural studies, 27, 209-219.

Lamine, C., 2012. Changer de système: une analyse des transitions vers l'agriculture biologique à l'échelle des systèmes agri-alimentaires territoriaux. Terrains et Travaux, 20, 139-156. 
Lamine, C. and Bellon, S., 2008. Conversion to organic farming: a multidimensional research object at the crossroads of agricultural and social sciences. A review. Agronomy for sustainable development, 29, 97-112.

Lamine, C., Darolt, M., and Brandenburg, A., 2012. The civic and social dimensions of food production and distribution in alternative food networks in France and Southern Brazil. International journal of sociology of agriculture and food, 19 (3), 383-401.

Lamine, C., Navarrete, M., and Cardona, A., 2013. Transitions towards organic farming at the farm and at the local scales: the role of innovative production and organisational modes and networks. In: S. Penvern, I. Savini, and S. Bellon, eds. Organic farming, prototype for sustainable agricultures? Paris, France: Springer, $423-438$.

Letourneau, D.K., et al., 2011. Does plant diversity benefit agroecosystems? A synthetic review. Ecological applications, 21, 9-21.

Lin, B.B., 2011. Resilience in agriculture through crop diversification: adaptive management for environmental change. Bioscience, 61, 183-193.

Liu, F. and Zhang, H., 2013. Novel methods to assess environmental, economic, and social sustainability of main agricultural regions in China. Agronomy for sustainable development, 33, 621-633.

Lopez-Ridaura, S., Masera, O., and Astier, M., 2002. Evaluating the sustainability of complex socioenvironmental systems. The MESMIS framework. Ecological indicators, 2, 135-148.

Marguerie, M., 2011. Diversification des cultures dans les exploitations maraîchères biologiques: conséquences sur les gestions agronomique et commerciale. Cas de la basse vallée de Durance, PACA. Engineer report, Supagro Montpellier, France.

Mijatovi, D., et al., 2013. The role of agricultural biodiversity in strengthening resilience to climate change: towards an analytical framework. International journal of agricultural sustainability, 11, 95-107.

Navarrete, M., 2009. How do farming systems cope with marketing channel requirements in organic horticulture? The case of market-gardening in south-eastern France. Journal of sustainable agriculture, 33, $552-565$.

Navarrete, M., et al., 2006. Combining leeway on farm and supply basin scales to promote technical innovations in lettuce production. Agronomy for sustainable development, 26, 77-87.

Nettier, J.B., et al., 2012. 'Conversion to organic farming and consequences on work organisation and work perception', The 10th European IFSA symposium, 164 jul. 2012, Aarhus, Denmark.

Ollivier, G. and Bellon, S., 2013. Dynamiques paradigmatiques des agricultures écologisées dans les communautés scientifiques internationales. Natures sciences société, 21, 166-181.

Paturel, D., 2010. Du maraîchage au maraîcher, le sens et les valeurs au travail, Séminaire franco-japonais, INRA, 20-21/04/2010, Montpellier, France.

Pelzer, E., et al., 2012. Assessing innovative cropping systems with DEXiPM, a qualitative multi-criteria assessment tool derived from DEXi. Ecological indicators, 18, 171-182.

Renting, H., Marsden, T., and Banks, J., 2003. Understanding alternative food networks: exploring the role of short food supply chains in rural development. Environment and planning A, 35, 393-411.

Rickson, R.E., Saffigna, P., and Sanders, R., 1999. Farm work satisfaction and acceptance of sustainability goals by Australian organic and conventional farmers. Sociological society rural sociology, 64, 266283.

Rigby, D. and Caceres, D., 2001. Organic farming and the sustainability of agricultural systems. Agricultural systems, 68, 21-40.

Rigby, D. and Young, T., 2000. Why do some agricultural producers abandon organic production systems? An exploration of UK data, Working paper $\mathrm{n}^{\circ} 0015$, University of Manchester.

Ripoll-Bosch, R., et al., 2012. An integrated sustainability assessment of Mediterranean sheep farms with different degrees of intensification. Agricultural systems, 105, 46-56.

Salmona, M., 1982. Les paysans français: le travail, les métiers, la transmission des savoirs. Paris, France: L'Harmattan.

Shreck, A., Getz, C., and Feenstra, G., 2006. Social sustainability, farm labor, and organic agriculture: Findings from an exploratory analysis. Agriculture and human values, 23, 439-449.

Smukler, S.M., et al., 2008. Transition to large-scale organic vegetable production in the Salinas Valley, California. Agriculture, ecosystems and environment, 126, 168-188.

Swift, M.J., Izac, A.M.N., and van Noordwijk, M., 2004. Biodiversity and ecosystem services in agricultural landscapes. Are we asking the right questions? Agriculture, ecosystems and environment, $104,113-134$.

Thompson, P.B., 1995. The spirit of the soil. Agriculture and environmental ethics. London: Routledge. 
Tovey, H., 1997. Food, environmentalism and rural sociology: on the organic farming movement en Ireland. Sociologia ruralis, 37, 21-37.

Van Cauwenbergh, N., et al., 2007. SAFE - A hierarchical framework for assessing the sustainability of agricultural systems. Agriculture, ecosystems \& environment, 120, 229-242.

Zander, K., 2008. Diversification and specialisation as development strategies in organic farms. 16th IFOAM Organic World Congress, 16-20/06/2008, Modena, Italy [online]. Available from: http:// orgprints.org/view/projects/conference.html

Zehnder, G., et al., 2007. Arthropod pest management in organic crops. Annual review of entomology, 52, $57-80$. 